7. Wedell A., Thilén A., Ritzén E.M. và cộng sự. (1994). Mutational spectrum of the steroid 21hydroxylase gene in Sweden: implications for genetic diagnosis and association with disease manifestation. J Clin Endocrinol Metab, 78(5),
1145-1152.

8. Narasimhan M.L. and Khattab A. (2019) Genetics of congenital adrenal hyperplasia and genotype-phenotype correlation. Fertil Steril, 111(1), 24-29

\title{
MỐI LIÊN QUAN GIŨ̃A CÁC YẾU TỐ THÚC ĐẨY VÀ MỨC Đô BÊ̂NH NÃO GAN LÂM SÀNG THEO TIÊU CHUẨN WEST HAVEN
}

\author{
Võ Duy Thông',2, Hồ Thị Vân Anh ${ }^{1}$
}

\section{TÓM TẮT}

Muc tiêu: Khảo sát mối liên quan giữa các yếu tố thúc đậ̉y và mức độ bệnh não gan (BNG) lâm sàng theo tiêu chuẩn West Haven. Đối tướng và phương pháp: Nghiên cứu cắt ngang mô tả tiến cứu được tiến hành trên 146 bênh nhân xơ gan có biến chứng BNG lâm sàng (BNG độ II, độ III và độ IV theo tiêu chuẩn West Haven). Tiêu chuẩn chẩn đoán xớ gan bao gồm hội chứng suy tế bào gan và hội chứng tăng áp lực tĩnh mach cửa; siêu âm bung hoắc chup cắt lớp vi tính (CT scan) bung cho thấy tổn thương gan mạn (cấu trúc thô, nhiều nốt tân sinh, bờ không đều...). Tiêu chuẩn chẩn đoán BNG lâm sàng bao gồm dựa vào đặc điểm lâm sàng của BNG và loại trừ các nguyên nhẩn khác gây rối loạn tâm thần kinh. Các yếu tố thúc đẩy gồm: Xuất huyết tiêu hoá, nhiễm trùng (Viêm phúc mac nhiễm khuẩn nguyên phát, nhiễm trùng hô hấp, nhiễm trùng tiểu...), hạ kali máu, hạ natri máu, táo bón, tiêu chảy và thuốc an thân. Kết quả: Tuổi trung bình là $51,24 \pm 13,37$, giới tính nam $(71,2 \%)$ nhiêu hơn nữ $(28,8 \%)$. Tỷ lê $\mathrm{BN}$ viêm gan vi rút $\mathrm{B}$ man chiếm phần lớn với $40,4 \%$, tiếp theo là rượu $(21,9 \%)$ và viêm gan vi rút $C$ man $(19,2 \%)$. Yếu tố nhiếm trùng chiếm tỷ lệ cao nhất $(54,1 \%)$, tiếp theo là hạ natri máu, xuất huyết tiêu hoá và hạ kali máu chiếm lần lượt là $37,0 \%, 36,3 \%$ và $33,2 \%$. Yếu tố nhiếm trùng và hạ natri máu có mối liên quan với mức độ bệnh não gan $(p=0,002$ và $p=0,001)$. Kết luận: Yếu tố nhiếm trùng và hạ natri máu có mối liên quạn với bênh não gan và mức độ nặng của bênh lý.

Tì̛ khóa: bệnh não gan, xỡ gan, yếu tố thúc đẩy, nhiếm trùng

\section{SUMMARY}

INVESTIGATION OF THE FACTORS RELATED TO THE SEVERITY OF CLINICAL HEPATIC ENCEPHALOPATHY BESED ON WEST HAVEN CRITERIA

Objective: To investigate the factors associated with the severity of clinical hepatic encephalopathy (BNG) based on West Haven criteria. Methods: A

${ }^{1}$ Đại học Y Dược Thành phố Hồ Chí Minh Bênh viên Chơ Rẫy, Thành phố Hồ Chí Minh

Chịu trách nhiệm chính: Võ Duy Thông

Email: duythong@ump.edu.vn

Ngày nhân bài: 19.01.2021

Ngày phản biên khoa hoc: 16.3.2021

Ngày duyệt bài: 26.3.2021 descriptive cross-sectional study was conducted on 146 cirrhotic patients with clinical complications of BNG (BNG grade II, III and IV according to West Haven criteria). Diagnostic criteria for cirrhosis include hepatocellular insufficiency syndrome and portal hypertension syndrome; abdominal ultrasound or computed tomography (CT scan) of the abdomen with chronic liver damage (rough structure, many neoplastic nodules, irregular margins...). Diagnostic criteria for clinical BNG include clinical characteristics of BNG with excluding other causes of psychosis. The factors including gastrointestinal bleeding, infection (primary infectious peritonitis, respiratory infection, urinary tract infection...), hypokalemia, hyponatremia, constipation, diarrhea and anesthetics were analyzed. Results: The mean age was $51.24 \pm 13.37$, the male gender rate was $71.2 \%$, higher than that of the female $(28.8 \%)$. The proportion of patients with chronic hepatitis due to hepatitis $B$ virus accounted for $40.4 \%$, followed by alcohol $(21.9 \%)$ and hepatitis C virus $(19.2 \%)$. Infectious factor accounted for the highest proportion $(54.1 \%)$, followed by hyponatremia $(37 \%)$, gastrointestinal bleeding $(36.3 \%)$ and hypokalemia (32.3\%). Infectious factors and hyponatremia were associated with the severity of hepatic encephalopathy $(p=0.002$ and $p=0.001)$. Conclusion: Infectious factors and hyponatremia were associated with hepatic encephalopathy and the severity of the disease.

Keywords; hepatic encephalopathy, cirrhosis, predisposing factor, infection

\section{I. ĐĂT VẤN ĐỀ}

Bệnh não gan (BNG) ảnh hưởng đến chất lượng cuộc sống của bệnh nhân (BN), gây rối loạn hành vi và cảm xúc, rối loạn giấc ngủ, giảm sự tương tác với gia đình và xã hội, giảm khả nẳng thực hiện các công việc hằng ngày dễ dẫn đên tai nạn [1]. Bên cạnh đó, sự suy giảm nhận thức ở BN BNG dẫn đễn việc sử dụng những nguồn lực chăm sóc $y$ tế nhiêu hơn so với những biến chứng khác của bệnh gan [2]. Tại Hoa Kí, BNG là nguyên nhân nhập viện thường gặp thứ 2 ở $\mathrm{BN}$ xơ gan $(\mathrm{XG})$ và tỷy lệ hiện mắc của $\mathrm{BNG}$ lâm sàng ở thời điểm chẩn đoán XG là $10-14 \%$ [3]. Trong 5 năm sau chẩn đoán $X G$, nguy cơ xảy ra đợt BNG lâm sàng đầu tiên là $5 \%-25 \%$ và 
tùy thuộc vào những yếu tố thúc đẩy (YTTĐ) [4]. Những $B N$ đã từng có BNG lâm sàng một lần trước đây sẽ có nguy cơ tái phát BNG lâm sàng là $40 \%$ trong một năm, những $B N$ đã có hai đợt BNG lâm sàng thì nguy cơ tái phát đợt thứ ba là $40 \%$ trong 6 tháng, mặc dù được điều trị bằng lactulose [3]. Ngoài ra, BNG ảnh hưởng rất quan trọng lên sự sống còn của BN XG. Tiên lượng sống ở $\mathrm{BN}$ bị $\mathrm{BNG}$ lần đầu là $42 \%$ sau 1 năm và $23 \%$ sau 3 năm theo dõi [4]. Ở BN XG, BNG thường xảy ra do một hoặc nhiều YTTĐ. Các YTTÐ BNG thường được tìm thấy và nếu các yếu tố này được điều trị thích hợp thì BN BNG sẽ hồi phục tốt hơn. Do đó, việc phòng ngừa, xác định và điều trị các YTTĐ BNG là rất cần thiết giúp giảm tỷ lệ mắc BNG và cải thiện tiên lượng sống còn ở BN BNG [3]. Vì vậy, chúng tôi tiến hành nghiên cứu này nhằm khảo sát mối liên quan giữa các yễu tố thúc đẩy và mức độ bệnh não gan lâm sàng theo tiêu chuẩn West Haven.

\section{II. ĐỐI TƯỢNG VÀ PHƯƠNG PHÁP NGHIÊN CỨU}

Thiết kế nghiên cứu: Nghiên cứu cắt ngang mô tả tiến cứu.

Đối tượng nghiên cứu: Tiêu chuẩn chọn bệnh nghiên cứu: Bệnh nhân đủ 18 tuổi trở lền được chẩn đoán xơ gan và BNG trên lâm sàng (BNG độ II, độ III và độ IV theo tiêu chuẩn West Haven) tại khoa Nội Tiêu hoá bệnh viện Chợ Rẫy từ tháng 10/2019 đến tháng 06/2020. Tiêu chuẩn chẩn đoán xơ gan: hội chứng suy tế bào gan và hội chứng tăng áp lực tĩnh mạch cửa; siêu âm bụng hoặc chụp cắt lớp vi tính (CT scan) bụng cho thấy tổn thương gan mạn (cấu trúc thô, nhiều nốt tân sinh, bờ không đều...). Tiêu chuẩn chẩn đoán BNG lâm sàng: dựa vào đặc điểm lâm sàng của BNG (rối loạn nhận thức, rối loạn giấc ngủ, thay đổi nhân cách, thay đổi hành vi, suy giảm ý thức, lời nói, dấu run vẫy...) và loại trừ các nguyên nhân khác gây rối loạn tâm thần kinh. Người thân của $\mathrm{BN}$ đồng ý tham gia nghiên cứu. Các yếu tố thúc đẩy gồm: Xuất huyết tiêu hoá, nhiễm trùng (Viêm phúc mạc nhiễm khuẩn nguyên phát, nhiểm trùng hô hấp, nhiễm trùng tiểu...), hạ kali máu, hạ natri máu, táo bón, tiêu chảy và thuốc an thần.

Tiêu chuân loại trừ: Bệnh nhân xơ gan có biểu hiện rối loạn tâm thần kinh do các nguyên nhân khác như bệnh lý ở não (xuất huyết não, nhồi máu não, viêm màng não, viêm não, áp xe não), nhiễm ceton acid, hạ đường huyết, bệnh lý tâm thần kinh.

Cỡ mẫu: Lấy mẫu thuận tiện.
Các bước tiến hành và phân tích số liệu. Bênnh sử chi tiết của từng $\mathrm{BN}$ được thu thập từ việc hỏi người chăm sóc BN. Các thông tin được thu thập bao gồm: Hỏi thông tin hành chính, bệnh sử, tiền căn và khám lâm sàng từng bệnh nhân. Ghi nhận các thông tin lâm sàng của bệnh nhân.

Kiểm soát sai lệnh thông tin: Định nghĩa rõ và cụ thể các biến số trong nghiên cứu. Nghiên cứu viên hiểu rõ bản chất dữ liệu và nắm vững phương pháp thu nhập dữ liệu. Đối với mỗi loại thông số, chỉ sử dụng thống nhất 1 thiết bị cân đo (máy xét nghiệm, siêu âm,..). Xử lý số liệu bằng phần mềm SPSS 22.

Vấn đề y đức: Nghiên cứu tiến hành đảm bảo tuân thủ các nguyên tắc đạo đức trong nghiên cứu $Y$ học và được Hội đồng nghiên cứu khoa học của Đại học Y Dược TP. Hồ Chí Minh thông qua.

\section{KẾT QUẢ NGHIÊN CỨU}

Đặc điểm dân số nghiên cứu. Tổng cộng có 146 bệnh nhận đủ tiêu chuẩn chọn mẫu và được đưa vào nghiên cứu. Đặc điểm dân số nghiên cứu được thể hiện tại Bảng 1. Kết quả nghiên cứu có tuổi trung bình là $51,24 \pm 13,37$ (nhỏ nhất là 29 và lớn nhất là 85 tuổi). Phân bố giới tính nam $(71,2 \%)$ nhiêuu hơn nữ $(28,8 \%)$ trong kết quả nghiên cứu. Khi khảo sát các nguyên nhân trong nghiên cứu, tỷ lệ $\mathrm{BN}$ viêm gan vi rút $B$ mạn chiếm phần lớn với $40,4 \%$, tiếp theo là rượu $(21,9 \%)$ và viêm gan vi rút $\mathrm{C}$ mạn $(19,2 \%)$. Khi khảo sát mức độ xơ gan theo thang điểm Child-Pugh, kết quả cho thây mức độ Child-Pugh $C$ chiến $78,1 \%$ và $20,5 \%$ có phân loại Child-Pugh $B$.

Bảng 1. Đặc điểm dân số nghiên cứu

\begin{tabular}{|c|c|}
\hline Đặc điểm & Tổng (n = 146) \\
\hline Tuối (năm) & $51,24 \pm 13,37$ \\
\hline Giới tính [n (\%)]: Nam & $104(71,2 \%)$ \\
Nữ & $42(28,8 \%)$ \\
\hline Nguyên nhân: HBV & $59(40,4 \%)$ \\
Rượu & $32(21,9 \%)$ \\
HCV & $28(19,2 \%)$ \\
NAFLD/NASH & $15(10,3 \%)$ \\
Khác & $12(8,2 \%)$ \\
\hline Phân độ Child-Pugh: A & $2(1,4 \%)$ \\
B & $30(20,5 \%)$ \\
C & $114(78,1 \%)$ \\
\hline
\end{tabular}

Các yếu tố thúc đẩy bệnh não gan

Kết quả nghiên cứu cho thấy, yếu tố nhiễm trùng chiếm tỷ lệ cao nhất trong các yếu tố thúc đẩy $(54,1 \%)$. Tiếp theo là hạ natri máu, xuất huyết tiêu hoá và hạ kali máu chiếm lần lượt là $37,0 \%, 36,3 \%$ và $33,2 \%$. Các yếu tố thúc đẩy 
khác như táo bón, tiêu chảy và thuốc an thần chiếm tỷ lệ thấp hơn với tỷ lệ lần lượt là 19,2\%,
14,2\% và 5,8\%. Tỷ lệ các yếu tố thúc đẩy được thể hiện ở Hình 1.

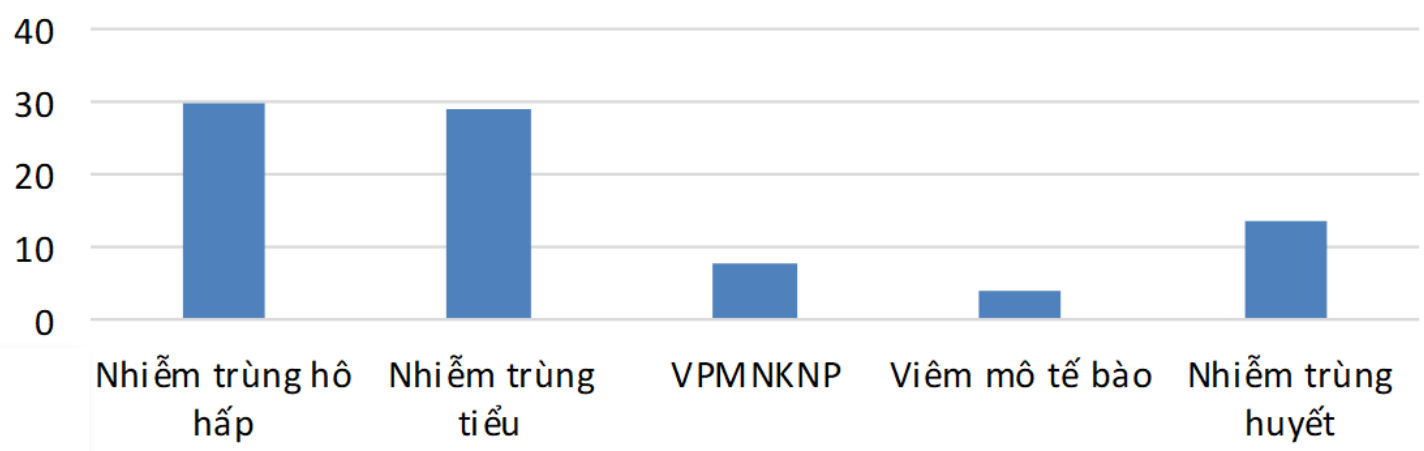

Hình 1. Tỷ lệ các yếu tố thúc đầy.

Yễu tố nhiễm trùng chiếm tỷ lệ cao, do đó khi phân tích các yếu tố nhiễm trùng, kết quả được thể hiện tại Hình 2. Chúng tôi ghi nhận, yếu tố nhiễm hô hấp chiếm tỷ lệ cao nhất $(29,8 \%)$, sau đó là nhiễm trùng tiểu với tỷ lệ là $29,1 \%$. Nhiễm trùng huyết, viêm phúc mạc nhiễm khuẩn nguyên phát và nhiễm trùng mô mềm chiếm tỷ lệ thấp hơn lần lượt là $13,6 \%, 7,5 \%$ và $3,8 \%$.

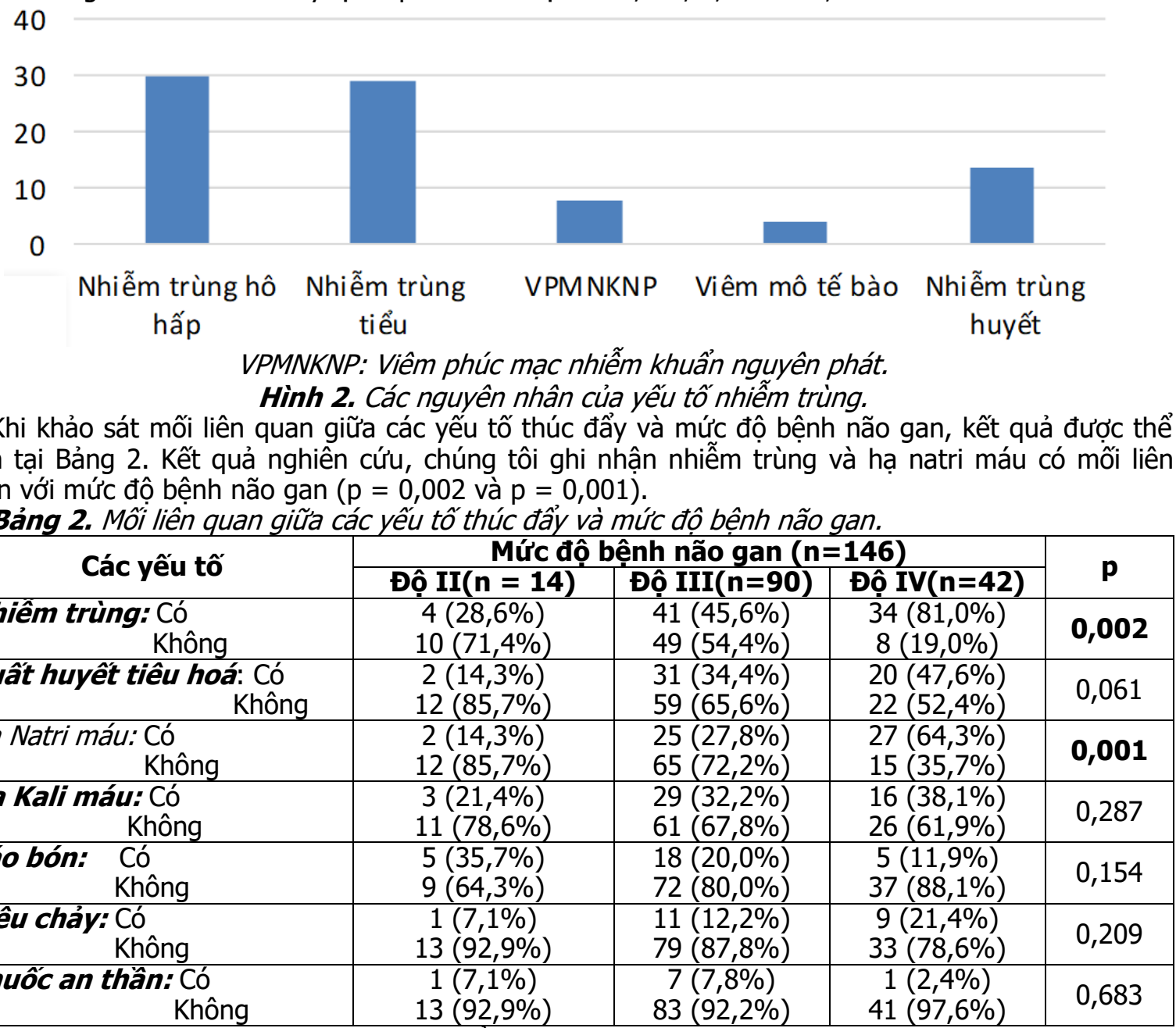

Khi đánh giá số lượng các yếu tố thúc đây và mức độ bệnh não gan, kết quả cho thấy có mối liên quan với $p<0,001$. 


\section{BÀN LUÂ̂N}

Trong nghiên cứu, chúng tôi nhận thấy tỷ lệ nam cao hơn nữ tương tự như nhiêu nghiên cứu trước đây, điều này có thể giải thích do việc uống rượu và chăm sóc sức khoẻ khác nhau giữa hai nhóm. Tỷ lệ các nguyên nhân gây xơ gan cũng thay đổi theo gian, nghiên cứu của Lê Hà Xuân Sơn cho thấy các nguyên nhân gây xơ gan theo thứ tự là HBV, HCV và rượu [5]. Tuy nhiên các nghiên cứu gần đây cho thấy các nguyên nhân theo thứ tự là HBV, rượu và HCV. Điều này có thể do tỷ lệ sử dụng rượu ngày càng cao, và các phác đồ điều trị HCV đạt hiệu quả cao. Trong các yếu tố thúc đẩy liên quan đến mức độ bệnh não gan, nghiên cứu của Lê Hà Xuân Sơnn [5] ghi nhận có mối liên quan giữa yếu tố nhiễm trùng với mức độ bệnh não gan $(p=0,014)$. Trong nghiên cứu của Mumtaz [6], tác giả tìm thây yếu tố rối loạn điện giải có mối liên quan với mức độ năng của bểnh não gan. Nghiên cứu của chúng tôi nhận thấy yếu tố nhiễm trùng và ha natri máu có mối liên quan với mức đô bênh nã்o gan $(p=0,002$ và $p=0,001)$. Bệnh nhân xơ gan dễ bi nhiễm trùng và khi nhiễm trùng thường diển tiến nặng hơn do tình tràng suy giảm miễn dịch. Nghiên cứu của Shawcross trên bệnh nhân xỡ gan cho thây tình trạng viêm và các chất trung gian gây viêm có thể điều chỉnh đáng kể ảnh hưởng của $\mathrm{NH} 3$ lên hệ thần kinh trung ương, gây suy giảm đáng kể tâm thần kinh và cải thiện sau khi giải quyết tình trang viêm [7]. Tình trạng đáp ứng viêm toàn thân hoặc nhiễm trùng được ghi nhận là góp phần làm trầm trọng thêm tình trạng bệnh não gan. Hệ thống miễn dịch ngoại biên thường sản xuất các cytokine gây viêm khác nhau, bao gồm interleukin- $1 \beta$ (IL-1 $\beta$ ), interleukin-6 (IL-6) và yếu tố hoại tử khối u (TNF-a) khi nhiếm trùng. Các cytokine này có thể trực tiếp đi qua hàng rào máu não hoặc tạo ra các tín hiệu gián tiếp lên não để tương tác với các cơ quan quanh não thất và kích hoat các tế bào thân kinh hướng tâm của dây thần kinh phế vị thông qua các chất dẫn truyền thần kinh khác nhau [8]. Một nghiên cứu khác đã cho thấy việc xóa gen quy định thụ thể IL-1 hoặc TNF-a làm trì hoãn khởi phát bệnh não và làm giảm phù não trong suy gan cấp. Ngoài ra, hạ thân nhiệt nhẹ dẫn đến giảm biểu hiện các cytokine tiền viêm lưu hành, cải thiện chức năng thần kinh, mức độ glutathione về bình thường và giảm tổn thương gan [4]. Điều này cho thấy nhiễm trùng hoặc đáp ứng viêm toàn thân là môt yếu tố quan trong góp phần vào mức độ nặng của bệnh não gan. Nhiễm trùng hô hấp và nhiễm trùng tiểu là các yếu tố thường gặp nhất trong nhóm yếu tố nhiễm trùng.

Các yểu tố thúc đẩy như xuất huyết tiêu hoá, biến chứng dãn tĩnh mạch thực quản có tỷ lệ cao ở một số nghiên cứu. Trong nghiên cứu của chúng, tỷ lệ yếu tố thúc đẩy của xuất huyết tiêu hoá chiếm $36,3 \%$. Việc sử dụng lợi tiểu không hợp lý hoặc không theo dõi điện giải đồ, có thể dẫn đến tình trạng rối loạn điện giải đồ. Bệnh nhân thường xuyên táo bón, dẩn đến việc tẳng $\mathrm{NH} 3$ và thúc đẩy bệnh não gan được trình bày ở nhiều nghiên cứu, và tỷ lệ $19,2 \%$. Hạ natri máu là biến chứng thường gặp ở bệnh nhân xơ gan tiến triển. Hạ natri máu có thể gây ra sự mất cân bằng thẩm thấu ở nhiều tế bào, bao gồm các tế bào não, sự giảm áp lực thẩm thấu của dịch ngoại bào sẽ làm các tế bào trương lên do nước từ ngoại bào di chuyển vào nội bào. Ở bệnh nhân xỡ gan, tăng NH3 máu sẽ gây tẳng glutamine trong các tế bào hình sao dấn đến tăng áp lực thẩm thấu nội bào nên dịch sẽ di chuyển tữ ngoại bào vào trong nội bào. Ha natri máu lại góp phần làm tăng thêm sự mất cân bằng thẩm thấu nên gây ra thêm một lượng nước từ ngoại bào vào nội bào làm nặng thêm tình trang phù tế bào. Các tế bào hình sao trương lên sẽ dẫn đến rối loạn chức năng tế bào hình sao, tạo điều kiện cho sự phát triển bệnh não gan. Các nghiên cứu thực nghiệm cho thây những con chuột tăng NH3 máu và hạ natri máu phát triển phù não nặng hơn những con chuột tăng NH3 máu và natri máu bình thường. Nghiền cứu ở người cho thây cả nồng độ NH3 máu và natri máu là những yếu tố chính quyết định bất thường điện não đồ ở bệnh nhân xơ gan [3], [7]. Trong các trường hợp hạ natri máu, mức độ natri máu từ $130 \mathrm{mmol} / \mathrm{L}$ đển dưới $135 \mathrm{mmol} / \mathrm{L}$, bệnh nhân thường không có triệu chứng lâm sàng nên các bác sĩ cần lưu ý theo dõi điện giải đồ để không bỏ sót và phòng ngừa natri máu tiếp tục hạ thấp ở những bệnh nhân này. Các bác sĩ cần phòng ngừa nhiếm trùng cho bệnh nhân nằm viện, kiểm soát tốt khi nhiếm trù̀ng xảy ra, thận trọng khi sử dụng thuốc lợi tiểu, theo dõi lượng nước xuất nhâpp và điện giải đồ thường xuyên. Bệnh nhân và người thân cần nhận thức được tẩm quan trọng của việc phòng ngừa nhiễm trùng, thực hiện đúng hướng dẫn hạn chế muối nước, sử dụng thuốc và tái khám theo đúng chỉ định. Ngoài ra, bệnh nhân và người thân cần được hướng dấn về các yếu tố thúc đẩy có thể phòng tránh được, người chăm sóc cần chú ý các bất thường ở bệnh nhân từ đó 
đưa bênh nhân đi khám để chẩn đoán, phát hiện và điều trị sớm các yếu tố thúc đẩy.

Nghiên cứu của chúng tôi ghi nhận càng nhiêu yếu tố thúc đẩy, bệnh não gan càng nặng. Do đó, số lượng các yếu tố thúc đẩy có mối liên quan đến mức độ bệnh não gan $(p=0,0001)$. Nghiên cứu của Muntaz, kết quả cho thấy số lượng từ hai yếu tố thúc đẩy trở lên có môi liên quan đến mức độ bênh não gan $(p=0,025)$, và những bệnh nhân có từ hai yếu tố thúc đẩy trở lên sẽ có bệnh não gan độ III hoặc độ IV lúc nhập viện [6]. Tương tự với nghiên cứu của Lê Hà Xuân Sơn [5], kết quả cũng tìm thây mỗi liên quan giữa số lượng yếu tố thúc đẩy và mức độ bệnh não gan $(p=0,019)$.

\section{KẾT LUÂN}

Yếu tố nhiễm trùng và hạ natri máu có mối liên quan với bệnh não gan và mức độ nặng của bệnh lý. Nghiên cứu cho thấy có sự liên quan giữa số lượng yếu tố thúc đẩy với mức độ bệnh não gan, do vậy phòng ngừa cũng như tầm soát các yếu tố thúc đẩy là cần thiết để hạn chế diễn tiến của bệnh não gan lâm sàng.

\section{TÀI LIỆU THAM KHẢO}

1. Agrawal S, Umapathy S, Dhiman RK. Minimal Hepatic Encephalopathy Impairs Quality of Life. Journal of Clinical and Experimental Hepatology. 2015; 5:42-48.

2. Quero Guillen JC, Herrerias Gutierrez JM. Diagnostic methods in hepatic encephalopathy. Clinica Chimica Acta. 2006; 365: 1-8.

3. Jepsen $P$, Ott $P$, Andersen $\mathbf{P K}$, Soresen $\mathbf{H T}$, Vilstrup $\boldsymbol{H}$. The clinical course of alcoholic liver cirrhosis: a Danish population-based cohort study. Hepatology. 2010; 51: 1675-1682.

4. Sharma BC, Sharma $P$, Agrawal A, Sarin SK Secondary prophylaxis of hepatic encephalopathy: an open-label randomized controlled trial of lactulose versus placebo. Gastroenterology. 2009; 137: 885-891.

5. Lê Hà Xuân Sơn. Khảo sát mối tương quan giữa các yếu tố thúc đẩy và tử vong trên bênh nhân Bệnh não gan loại C. Luận văn tốt nghiệp bác sĩ nội trú, Đại học Y khoa Pham Ngoc Thach. 2015. tr. 1-70.

6. Mumtaz K, Ahmed US, Abid S, Baig N, Hamid $\mathbf{S}$, Jafri W. Precipitating Factors and The Outcome of Hepatic Encephalopathy in Liver Cirrhosis. Journal of the College of Physicians and Surgeons Pakistan. 2010; 20(8):514-518.

7. Shawcross DL, Davies NA, Williams R, Jalan R. Systemic inflammatory response exacerbates the neuropsychological effects of induced hyperammonemia in cirrhosis. Journal of Hepatology. 2004; 40(2):247-254.

8. Atluri DK, Prakash R, Mullen KD. Pathogenesis, diagnosis, and treatment of hepatic encephalopathy. Journal of Clinical and Experimental Hepatology. 2011; 1(2): 77-86.

\section{KHẢO SÁT VÀ ĐÁNH GIÁ VIÊCC SỬ DỤNG KHÁNG SINH VANCOMYCIN TẠI BỆNH VIỆN ĐA KHOA ĐỒNG NAI}

\section{TÓM TẮT}

Kháng vancomycin đã làm dấy lên mối lo ngại về triển vọng hiệu quả trong điều trị bệnh nhân nhiếm khuẩn Gram dương. Nghiên cứu được thực hiện tại bệnh viên đa khoa Đồng Nai từ tháng 3/2019 đến tháng 6/2019. Phương pháp: Nghiên cứu hồi cứu để đánh giá việc kê đơn và sử dụng vancomycin tại bệnh viện. Kết quả được xác định và biểu thị bằng các liệu trình vancomycin trên 98 bệnh nhân nhập viện. Thông tin về bệnh nhân được thu thập bao gồm: nhân khẩu học, căn nguyên và vị trí của nhiễm trùng, dữ liệu vi sinh, chế độ liều lượng, cách dùng và thời gian điều trị, độc tính trên thận của vancomycin. Kết quả: Tuổi trung bình và thời gian điều trị vancomycin lần lượt là 56 tuổi và 9 ngày. Nhiễm trùng da mô mêm (44\%) là nguyên nhân phổ biến nhất. Can thiệp y tế chủ yếu là

${ }^{1}$ Đại học Lạc Hồng, Đồng Nai

Chịu trách nhiệm chính: Đinh Thị Thúy Hà

Email: Dinhthuyha85@gmail.com

Ngày nhận bài: 18.01.2021

Ngày phản biên khoa họ: 16.3 .2021

Ngày duyệt bài: 23.3.2021
Đinh Thị Thúy Hà ${ }^{1}$

thở máy $(28,6 \%)$. Số lượng bệnh nhân có kết quả khỏi, đỡ, giảm chiếm tỉ lệ cao $(66,3 \%)$. Chế độ liều nạp được áp dụng ở 13,3 \% bệnh nhân với liêu nạp thễo cẩn nặng $25,6 \mathrm{mg} / \mathrm{kg}$. Đa số bệnh nhân trong mẫu nghiên cứu dùng chế độ liều ban đầu $1 \mathrm{~g} / 12$ giờ (78,6\%) khi chức năng thận bình thường. $100 \%$ bênh nhân được sử dụng đường truyền tĩnh mạch ngắt quảng, 96,9\% trường hợp có dung môi pha truyền hợp lý, $100 \%$ phù hợp về thời gian truyền và $63,2 \%$ phù hợp về nồng độ truyền. 7 bệnh nhân có sự thay đổi creatinine huyết thanh (tăng $>50 \%$ so với giá trị ban đâu), đều xuất hiện ít nhất sau 7 ngày, muộn nhất sau 14 ngày sử dụng vancomycin. Kết luận: Cần có các chương trình toàn diện để cải thiện việc sử dung vancomycin trong các bệnh viên. Việc sử dụng Vancomycin nên được theo dõi để tổi ưu hóa việc sử dụng thuốc.

Tư khóa: vancomycin, sử dụng thuốc

\section{SUMMARY \\ EVALUATION OF VANCOMYCIN USE AT DONG NAI GENERAL HOSPITAL}

Objectives: Vancomycin resistance has raised concerns about outcome prospects in the treatment of 